\title{
Distinction Awards: the system in Scotland
}

The distinction award system in Scotland is arranged through a hierarchy of meetings. At the apex is the Scottish Sub-Committee, supported by a Scottish C Awards Committee and a system of regional meetings. Preliminary meetings are arranged on an area or speciality group basis. A system of 12 Regional Advisers. appointed by the Chairman of the Scottish Sub-Committee, also exists to facilitate the work of the Scottish Sub-Committee and the various regional meetings.

\section{The Scottish Sub-Committee}

The Scottish Sub-Committee has six members. These comprise the Chairman, three members representing the Royal College of Physicians of Edinburgh, the Royal College of Physicians and Surgeons of Glasgow and the Royal College of Surgeons of Edinburgh, one member appointed by the Scottish Committee for Hospital Medical Services, and the Chief Executtive of the National Health Service in Scotland. The Chief Medical Officer and Chief Dental Officer of the Scottish Office Home and Health Department have observer status. The Regional Advisers are also in attendance.

The Scottish Sub-Committee receives nominations for $\mathrm{C}$ awards from the Scottish C Awards Committee, nominations for higher (A and B) awards from the Regional Higher Awards Meetings and the Chairman receives nominations for At awards from current At award holders.

\section{The Scottish C Awards Committee}

The Scottish C Awards Committee has 25 members, consisting of the six members of the Scottish Sub-Committee, the 12 Reglonal Advisers, three Chairmen of NHS Trusts or Health Boards, and four Chief Executives of NHS Trusts or General Managers of Health Boards. The Chief Medical Officer and the Chief Dental Officer of the Scottish Office Home and Health Department have observer status. The Chairman of the Scottish Sub-
Committee chairs the Scottish C Awards Committee.

The Scottish C Awards Committee receives nominations for $\mathrm{C}$ awards from seven Regional C awards Meetings, and determines which nominations to submit to the Scottish SubCommittee, in the light of the number of awards known to be available for allocation by the time that the Scottish C Awards Committee meets.

\section{Regional Awards Meetings in Scotland}

The terms Region and Regional have been retained in Scotland for distinction awards purposes only, based on the five former Scottish Hospital Board Regions. Regional Higher Awards Meetings for considering A award nominations are held in the four Regions that contain the Scottish Medical Schools, and the Scottish Sub-Committee is responsible for seeking nominations for A awards in respect of consultants employed in the Northern Region.

\section{The Royal College of Psychiatrists 'System in Scotland'}

The Chairman of the Scottish Divison calls an Annual Meeting (usually at the end of January or the beginning of February) to which are invited all existing $A$ and $A+$ award holders, the Secretary of the Division, and senior award holders in the six specialities (adult mental illness, psychotherapy, old age psychiatry, child and adolescent psychiatry, forensic psychiatry and mental handicap). Merit award holders advise on recommendations for up to and including their own grade, but not for higher awards and are not present at these discussions. Participants at the meeting are circulated with lists of all consultant psychiatrists in Scotland. At the meeting the Chairman reads out each name giving an opportunity for those present to identify candidates for awards. There is a quota of merit awards in each grade and recommendations are prioritised. The 
recommendations then go forward to ACDA Secretary at the Common Services Agency in Edinburgh together with citation forms which are prepared by a member of the Scottish Division Merit Awards Committee. The Chairman also informs the President of the
College of the nominations of the Scottish Division.

R. G. McCreadie, Chairman, Scottish Division, Royal College of Psychiatrists, 9 Queen Street, Edinburgh EH2 1JQ

\section{Distinction Awards: how the Northern Ireland scheme is organised}

The scheme is based on a system of peer review and is controlled by the Distinction and Meritorious Service Awards Committee. The DMSAC advises the Department which consultants engaged in the Health Service should receive awards for professional distinction and in so doing seeks to ensure that no consultant who has been nominated from whatever source fails to receive fair consideration and that the purpose behind the scheme is being fulfilled.

The Committee is appointed by the Head of the Department of Health and Social Services with the concurrence of the relevant Minister. Members are appointed in the first instance for three years on a rotational basis, with provision for re-appointment for a second term.

Vacancies occur at the end of each year when the Committee is reconstituted. The current membership is:

Chairman Mr D. S. Gordon CBE

\author{
Members Professor J. W. Dundee OBE \\ Professor J. E. Cooper \\ Professor M. McGeown CBE \\ Professor B. M. Hibbard \\ Professor M. Rosen CBE \\ The Rt Hon Lord Justice \\ O'Donnell QC \\ Mr P. G. Kinder CBE
}

Of these members, three are consultants from Great Britain appointed with a view to ensuring parity of standards throughout the United Kingdom, three are retired consultants from Northern Ireland who are of such standing as to have no personal interest in the allocation of awards. Of the remaining members one is the General Manager of the Eastern Health and Social Services Board while the other is a retired Lord Justice of Appeal of the Supreme Court whose role is to ensure that consistent standards are maintained. 